\title{
Simulation on stream flow and nutrient loadings in Meiling watershed, Taihu Lake Basin, based on SWAT model
}

\author{
Lan-Lan Song ${ }^{\mathrm{a}, \mathrm{b}},{ }^{\dagger}$ and Jun-Liang Jin ${ }^{\mathrm{b}}$ \\ ${ }^{a}$ State Key Laboratory of Hydrology-Water Resources and \\ Hydraulic Engineering, \\ Hohai University, \\ Nanjing 210098, China \\ ${ }^{b}$ Research Center for Climate Change, MWR. \\ Nanjing, 210029, China \\ ${ }^{\dagger}$ E-mail: Lanlan_song@hhu.edu.cn
}

\begin{abstract}
A distributed watershed hydrologic model, SWAT was applied to simulate stream flow and nutrient loadings ( $\mathrm{TN}, \mathrm{NO}_{3}^{-}, \mathrm{TP}$ ) in Meiling watershed, which is sub-watershed of Taihu Lake Basin. Model parameters were calibrated and validated using the measured data. The results were satisfactory; the evaluation coefficients for daily calibration were: Person's correlation coefficient is 0.73 , Nash-Sutcliffe coefficient is 0.63 . The simulated daily mean value of TN and TP were $1.545 \mathrm{~kg} / \mathrm{ha}$ and $0.025 \mathrm{~kg} / \mathrm{ha}$, close to the measured value, viz. $1.901 \mathrm{~kg} / \mathrm{ha}$ and $0.043 \mathrm{~kg} / \mathrm{ha}$ respectively, suggesting the validity of SWAT. The simulation provides better understanding on stream flow and nutrient loading in response to agricultural tillage operation and natural rainfall.
\end{abstract}

Keywords: Non-Point Source Pollution; Taihu Lake Basin; Nutrient Load; SWAT.

\section{Introduction}

China has undergone a rapid change and economic growth, especially in the populated and developed region of Taihu Lake basin. With the rapid economic development and population increase, more and more pollutant release deteriorated the lake water quality. In 1998, the government took the 'Emission Control' action to control point source of Taihu Lake. But there is no significant improvement by comparing water quality between 1998 and 1999[1]. This shows that non-point source contaminants are probably the major causes. Nonpoint sources contribute to excess phosphorus and nitrogen in surface water which can further excessive algae and aquatic plant growth in urban and agricultural streams. Excess algal growth and decomposition can lead to water odor and taste problems, fish kills, and other environmental and aesthetic

\footnotetext{
$\dagger$ Work partially supported by by grant $41401024,41401026,41330854,41371063$ of National Natural Science Foundation of China and grant 2016YFA0601501,2016YFC0401501 National Key Research and Development Plan..
} 
problems[2]. Eutrophication was recognized as a pollution problem in Taihu Lake. Surveys showed that the area of algal bloom amounted to $760 \mathrm{~km}^{2}$, accounting for 1/3 of total lake area in April and May 2007[3]. Taihu Lake basin has major water management problems related to pollution originating from agriculture linked mostly to fertilization and application of pesticides. Agriculture can have a detrimental effect on water quality leading to acute problems such as erosion, salinization, and diffuse pollution by nutrients and pesticides[4]. Therefore, elevated $\mathrm{N}$ and $\mathrm{P}$ levels have been identified in the hillside of Taihu Lake Basin.

Contaminant transfer via runoff is a complex function of rainfall timing, antecedent hydrology, slope and soil characteristics and of the properties of the contaminant under consideration. A number of models were reviewed in terms of their potential for predicting diffuse-source transfer, such as ANSWERS[5;6]; SWATCATCH[7], and SWAT[8]. Of these, SWAT was considered to be a bestachieve model which is a physically based, continuous time model[9] and a well-established model for analyzing the impacts of land management practices on water, sediment, and agricultural chemical yields in large complex watersheds[10;11].as diffuse source pollution control of land use and management is a key procedure, SWAT offer flexibility for defining and valuating sustainable and low environmental impact farming practices[12]. In recent decade, it has been preliminarily applied to some watersheds in china(i.e. East River[13], Yellow River[14], Luohe River[15], Honghu[16], Taihu Lake[17] and Poyang Lake[18]). The simulation for Taihu Lake is deemed to fail to predict accurately the monthly-runoff partly due to the lack of detailed artificial river network data[19].

The paper perform the SWAT(Soil and Water Assessment Tool) in Meiling water shed to evaluate how much effect agricultural tillage management have on water resources.

\section{Study Area}

Located about $9 \mathrm{~km}$ from Lake Taihu, Meiling water shed(119 $51^{\prime} \mathrm{E}$ and $\left.31^{\circ} 20^{\prime} \mathrm{N}\right)$ area is 122ha (Figure 1). The terrain is higher in the south and the maximum and minimum altitude is $60 \mathrm{~m}$ and $3 \mathrm{~m}$, respectively. The region is 'subtropical monsoon', warm and wet. The mean annual rainfall is about $1177 \mathrm{~mm}$, although it shows high intra- and inter-annual variability. The mean temperature is $15.7^{\circ} \mathrm{C}$, with the highest temperature of $28.3^{\circ} \mathrm{C}$ in summer. The frost free periods and growth period are estimated to be $240 \mathrm{~d}$ and $250 \mathrm{~d}$, respectively.

Land use is most dedicated to silviculture and husbandry at the foot slope of the mountains and in the terraces. The internal plains extending northeast are the areas for rice and dry land. The slope land is planted with Chinese nut, tea and 
orchard. The fir tree and bamboo are in the high altitude hillside. About $75 \%$ of the basin is under cultivation. About $91 \%$ of the soils are yellow-brown soil, with the rest being paddy soil. There is no discharge of industrial and municipal waste water within the study area.

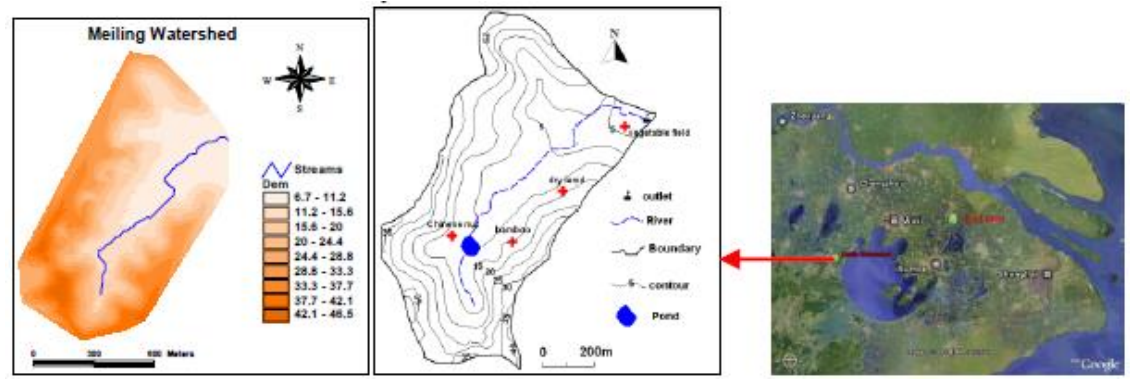

Fig. 1. This is the caption for the figure. If the caption is less than one line then it needs to be manually centered.

\subsection{Methodology}

A free-flow rectangular overflow weir were built at the out let to monitoring flow and water quality. Daily soil moisture from the automatic data loggers (TD Divers)was obtained from May 25 to Oct 13, 2006. Daily precipitation and rainfall duration are recorded by the auto rain monitors. Daily temperature was recorded from Jan to Oct. 2006.

\subsubsection{Principles of SWAT model}

SWAT was developed to simulate a number of different physical processes in a basin. The hydrologic cycle as simulated by SWAT is based on the water balance equation. The simulated hydrological processes include surface runoff (SCScurve number or Green and Ampt infiltration equation), percolation, lateral flow, groundwater flow from shallow aquifers to streams, evapotranspiration (Hargreaves, Priestley-Taylor or Penman Monteith method), snowmelt, transmission losses from streams(Muskingum routing method) and water storage and losses from ponds.

\subsubsection{SWAT model input data}

Five major datasets were required: land use map, soil map, a digital topographic map, digital river network, and a climatic database. DEM and land use were measured with accuracy of $1 \times 1 \mathrm{~m}$ (Figure 1).According DEM, 4 sub basins were obtained with 5-ha-threshold-area value. A $20 \%$ threshold for land use and a $10 \%$ threshold for soil type were used, which finally resulted in 14 HRUs. Four types of land use: vegetable field, dry land, bamboo, and Chinese nut, were chosen for 
the runoff test plots. Soil samples from these runoff test plots were analyzed(Table 1).During post- and pre-rainfall, TN and TP were analyzed of soil sin run off plots.Dates of fertilizer applications of each cropping system were recorded(Table 2). During rainfall, the water samples were collected every 10 minutes in four runoff plots and analyzed $\mathrm{N}$ and $\mathrm{P}$ concentration.

Table 1. Main characteristic of considered soil types

\begin{tabular}{lll}
\hline Soil name & Yellow-brown soil & Paddy soil \\
\hline Clay (\% fine fraction) & 18.9 & 23.8 \\
Silt (\% fine fraction) & 58.2 & 64.5 \\
Sand (\% fine fraction) & 22.9 & 11.7 \\
Organic content $(\%$ weight) & 1.9 & 1.3 \\
Bulk density $\left(\mathrm{g} / \mathrm{cm}^{3}\right)$ & 1.3 & 1.2 \\
Total porosity $(\%)$ & 52.8 & 53.2 \\
Field moisture capacity $(\%)$ & 47.9 & 47.5 \\
Wilting coefficient $(\%)$ & 31.2 & 34.3 \\
Soil hydrologic group & $\mathrm{B}$ & $\mathrm{C}$ \\
\hline
\end{tabular}

Table 2. Fertilizer of Meiling Watershed

\begin{tabular}{lllll}
\hline \multirow{2}{*}{ sites } & Time of & \multicolumn{2}{l}{ quantity of fertilizer / $\mathrm{kg} \cdot \mathrm{ha}^{-1}$} & \multirow{2}{*}{ crops } \\
& fertilization & Elemental Nitrogen & Elemental phosphorous & \\
\multirow{2}{*}{ Rice field } & Jun. 5, 2006 & 115.73 & 58.25 & rice \\
& Jun. 26, 2006 & 57.50 & 5.75 & \\
& Jul. 30, 2006 & 31.00 & 2.25 & Pumpkin, \\
\multirow{2}{*}{ Vegetable field } & April 10,2006 & 600.00 & 168.75 & eggplant, water \\
& Jul. 11,2006 & 230.00 & 0.00 & spinach \\
\multirow{2}{*}{ Dry land } & Sept. 5,2006 & 625.00 & 500.00 & garlic \\
\hline
\end{tabular}

\subsection{Results and discussion}

\subsubsection{Model calibration and validation}

From May 25 to Jul. 15, 2006 was selected as calibration period.The model was manually calibrated by optimizing Pearson's correlation coefficient $(r)$ and NashSutcliffe's efficiency (NSE). The calibration goal of NSE $>0.5$ and $r>0.8$ were attained on a daily time step, which indicates that the model accurately simulates temporal changes as well(Table 3). A sensitivity analysis found SCS curve number (CN2), effective hydraulic conductivity in main channel ( $\left.\mathrm{CH} \_\mathrm{K} 2\right)$, base flow recession coefficient (ALPHA_BF), the soil evaporation compensation factor (ESCO), the available water capacity (SOL_AWC), base flow alpha factor(ALPHA_BF)and groundwater delay (GW_DELAY) were sensitive parameters(Table 4). 
Table 3. Statistical indexes for the daily flow during calibration and validation periods

\begin{tabular}{lll}
\hline & Calibration (daily) & validation (daily) \\
\hline $\mathrm{r}$ & 0.73 & 0.85 \\
$\mathrm{NSE}$ & 0.63 & 0.90 \\
\hline
\end{tabular}

Table 4. Initial and final values for the calibrated variables

\begin{tabular}{lll}
\hline Parameters & Initial value & Final value \\
\hline CN2 & Initial SCS curve number for moisture condition II & CN2 \pm 10 \\
ESCO & 0.95 & 1 \\
CH_K2 & 0 & 60 \\
SOL_AWC & AWC & AWC \pm 0.04 \\
ALPHA_BF & 0.048 & 0.01 \\
GW_DELAY & 31 & 1 \\
\hline
\end{tabular}

Visually from Figure 2, a good adjustment is observed except in peak rainfall. A single rainstorm occurred on July 5 and July 8 with 24 h rainfalls amounting over $50 \mathrm{~mm}$. The measured peak flow of outlet showed that the lag time was less than $4 \mathrm{~h}$. while recording the water level of weir at each $30 \mathrm{~min}$, this may ignored the change of storm rainfall and implied a significant error in the calculation of input.

From Jul. 15 to Oct. 13, 2006 was validation period. $r$ values improved during validation period (Table 4). There is a significant increase in runoff volume deviation. These deviations are mainly explained that there are a few intense rainfalls in validation period.

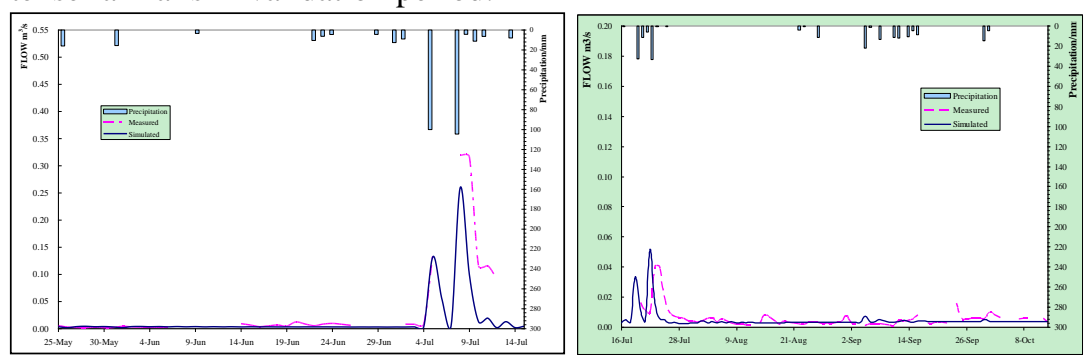

Fig. 2. Compare of simulated and measured stream flow(Left: calibration; Right: validation)

\subsubsection{Nutrients data}

The nutrient species simulated by SWAT includes $\mathrm{NO}_{3}^{-}, \mathrm{DP}, \mathrm{ORG}-\mathrm{N}$, and ORG-P. checking the initial concentrations of the nutrients in the soil is the first step of nutrient calibration(.chm, .sol input files). SWAT simulates $\mathrm{N}$ and $\mathrm{P}$ cycle fore very HRU. The decay, mineralization, and nitrification parameters were adjusted in calibration. Simulated and measured average daily nutrients load were listed from Jun. 17 to Jul. 23 after fertilizer application(Table 5). 
Except TP was under-predicted, the others are greater than 0.40 . In china, most of suburbs of soil phosphorus content were more than $25 \mathrm{mg} / \mathrm{kg}$ of critical level. Therefore, phosphorus load was lower than the measured value. The simulated daily mean value of TN and TP were $1.545 \mathrm{~kg} / \mathrm{ha}$ and $0.025 \mathrm{~kg} / \mathrm{ha}$, close to the measured value, viz. $1.901 \mathrm{~kg} / \mathrm{ha}$ and $0.043 \mathrm{~kg} / \mathrm{ha}$ respectively, which verdict that the simulation was basically acceptable.

Table 5. Comparison on simulated and measured average daily and annual load of TN, $\mathrm{NO}_{3}{ }^{-}$and TP in 2006

\begin{tabular}{llll}
\hline Nutrients & $\mathrm{TN}$ & $\mathrm{NO}_{3}{ }^{-}$ & $\mathrm{TP}$ \\
\hline daily average load (Measured value, $\mathrm{kg} / \mathrm{ha})$ & 1.901 & 0.243 & 0.043 \\
daily average load (Simulated value, $\mathrm{kg} / \mathrm{ha})$ & 1.545 & 0.240 & 0.025 \\
Annual average load (Measured value, $\mathrm{kg} / \mathrm{ha})$ & 269.9 & 34.5 & 6.1 \\
Annual average load (Simulated value, $\mathrm{kg} / \mathrm{ha})$ & 219.3 & 34.1 & 3.6 \\
$r$ & 0.77 & 0.43 & 0.36 \\
NSE & 0.72 & 0.40 & 0.10 \\
\hline
\end{tabular}

\section{Conclusions}

The hydrological model SWAT was applied to a part of the Taihu Lake basin. The measured data from Meiling watershed was used to assess the performance in simulating hydrologic and water quality responses. SWAT was rather successful in reproducing water flow and showed good performance in the study area as a whole with $r$ value over 0.80 on daily scales for both calibration and validation periods. However, the performance was poor when simulation high flows, especially in high intensity rain events.

The model was able to predict the range of nutrient load in surface water. Daily nutrient output varied mostly due to surface runoff and agricultural tillage operation, e.g. fertilizer application time and crop rotation system. By SWAT and field experiment, the estimations demonstrated that TP, TN and $\mathrm{NO}_{3}{ }^{-}$load agreed well with the measured data.

The interface of SWAT is user-friendly, and most of parameters are automatically generated from GIS data or other information and relatively easy to adjust with proper instruction. But the SWAT can't model sub-daily runoff, sediment and nutrient losses during very high intensity rain events. This is recommended for further studies to time scale from daily to sub-daily which makes SWAT to be used more widely.

This study set the platform for future studies where the calibrated and validated SWAT can be used to Taihu hilly areas and evaluate agriculture tillage operation to reduce erosion and nutrient losses from the watershed. The other alternative land management practices such as land use conversions, which also cause better regional environmental quality, were not modeled. Certainly, the 
experiments on runoff test plots are proceeding to study agriculture activities impact on groundwater quality. If possible, and further be improved and perfected.

\section{References}

1. Zhang W., Wang X., Jiang Y., 2001.Effect of Emission Control on Water Quality of the Taihu Lake. Rural Eco-environment 17(1), 44-47(in Chinese)

2. TCEQ.2003a. Reducing phosphorus in the North Bosque River: Taking action to improve water quality. Austin, Texas: Texas Commission on Environmental Quality.

3. Zhang L., Xia M., Zhang L., Wang C., Lu J., 2008.Eutrophication status and control strategy of Taihu Lake. Frontiers of Environmental Science \& Engineering in China.2(3), 1673-7415

4. Zalidis, G., Stamatiadis, S., Takavakoglou, V., Eskridge, K., Misopolinos, N., 2002. Impacts of agricultural practices on soil and water quality in the Mediterranean region and proposed assessment methodology. Agrc. Ecosyst. Environ. 88, 137-146

5. Beasley, D.B., 1991. ANSWERS User's Manual Second Edition Agricultural Engineering Department. University of Georgia, Tifton, GA, USA

6. Bouraoui, F., Dillaha, T.A., 1996. ANSWERS-2000: runoff and sediment transport model. Journal of Environmental Engineering 126(11), 1045-1055

7. Holman, I.P., Hollis, J.M., Alavi, G., Bellamy, P.H., Jarvis, N., Vachaud, G. Loveland, P.J., Gardenas, A., Tao C Bo, C.J., Kreuger, J., 2001. CAMSCALE-upscaling Predictive Models and Catchment Water Quality. Draft Final Report to DGXII, Commission of the European Communities under Contract ENV4-CT97-0439

8. Arnold, J.G., Allen, P.M., Bernhardt, G., 1993. A comprehensive sufacegroundwater flow model. Journal of Hydrology 142, 47-69

9. Arnold, J.G., Srinivasan, R., Muttiah, R.S., Allen, J.R., 1998. Large area hydrologic model in grand assessment. Part I: model development. Journal of American Water Resources Association 34(1), 73-89

10. Di Luzio, M., Srinivasan, R., Arnold, J., 2002.Arcview Interface for SWAT2000 User's Guide.Published by Texas Water Resources Institute TR-193, College Station, TX. 324-357

11. Setegn, S.G., Srinivasan, R., Dargahi, B., 2008. Hydrological Modelling in the Lake Tana Basin, Ethiopia Using SWAT Model. The Open Hydrologh Journal, 2, 49-62 
12. Kannan, N., White, S.M., Worrall, F., Whelan, M.J., 2007.Hydrological modeling of a small catchment using SWAT-2000 -Ensuring correct flow partitioning for contaminant modeling. Journal of Hydrology 334, 64-72

13. Chen, J., 2008, Exploring hydrological process features of the East River(Dongjiang) basin in south china using VIC and SWAT. Hydrological sciences for managing water resources in the Asian developing world , 116123

14. Zhang, X., 2008.Runoff simulation of the headwaters of the Yellow River using the SWAT model with three snowmelt algorithms. Journal of the American water resources association 44(1), 48-61

15. Luo Y., 2008. Assessment of crop growth and soil water modules in SWAT2000 using extensive field experiment data in an irrigation district of the Yellow River Basin. Journal of Hydrology 352(1/2 ), 139-156

16. Gui, F., Yu,G., Lai, G., 2006. Historical simulations of nutrient sedimentary and transport changes in Hongu Lake Basin. Actasedimentologica Sinica 24(3), 333-338 (in Chinese)

17. Lai G., Gui, F., 2006. Preliminary study on assessment of nutrient transport in the Taihu Basin based on SWAT modeling. Science in China (Series D. Earth Sciences) 49 (Supp. 1), 135-145

18. Guo, H., 2008. Annual and seasonal streamflow responses to climate and land-cover changes in the Poyang Lake Basin, china. Journal of Hydrology 355(1/4), 106-122

19. Huang, Z., Xue, B., Pang, Y., 2009, Simulation on stream flow and nutrient loadings in Gucheng Lake, Low Yangtze River Basin, based on SWAT model. Quaternary International 208, 109-115 